Chirurgia (2018) 113: 464-468

No. 4, July - August

Copyright@ Celsius

http://dx.doi.org/10.21614/chirurgia.113.4.464

\title{
New Definitions of Sepsis and the Quest for Specific Biomarkers. Are the miRNAs the Answer?
}

\author{
Gratiela Manga', George A. Calin ${ }^{2}$, Mircea Manuc ${ }^{3,4}$, Gabriela Droc ${ }^{1,4}$, Stefan Tudor ${ }^{5}$ \\ 'Department of Anaesthesia and Intensive Care, Fundeni Clinical Institute, Bucharest, Romania \\ 2Department of Experimental Therapeutics, The University of Texas MD Anderson Cancer Center, Houston, TX, USA \\ The Center for RNA Interference and Non-coding RNAs, The University of Texas, MD Anderson Cancer Center, Houston, TX, USA \\ ${ }^{3}$ Department of Gastroenterology and Hepatology, Fundeni Clinical Institute, Bucharest, Romania \\ 4"Carol Davila" University of Medicine and Pharmacy, Bucharest, Romania \\ ${ }^{5}$ Department of General Surgery, Fundeni Clinical Institute, Bucharest, Romania
}

Corresponding authors:

Stefan Tudor, MD

Fundeni Clinical Institute

258 Fundeni Street, Bucharest, RO

E-mail: stefantudor@gmail.com

Assoc. Prof. Gabriela Droc Fundeni Clinical Institute

258 Fundeni Street, Bucharest, RO

E-mail: gabidroc@gmail.com
Received: 06.02.2018 Accepted: 30.06 .2018

\section{Rezumat \\ Noile definiții ale sepsisului; rolul microARN-urilor ca biomarkeri specifici}

Sepsisul reprezintă o boală sistemică caracterizată de disfuncția acută de organ determinată de infecție. Diagnosticul precoce, evaluarea severitătii sepsisului, resuscitarea agresivă şi administrarea adecvată a antibioticelor sunt asociate cu o evoluție favorabilă. O gama largă de biomarkeri au fost propuşi pentru diagnosticul sepsisului, mult mai mulți decât în alte boli, demonstrând astfel complexitatea acestei patologii. În primul studiu ce demonstrează valoarea clinică a miRNA în sepsis, autorii au arătat că nivelurile de miR-150 la nivel leucocitar şi plasmatic sunt reduse semnificativ la pacienții cu sepsis vs. control şi, de asemenea, sunt corelate cu gradul de severitate al sepsisului. In 2016 a fost propusă o nouă definiție a sepsisului (Sepsis-3). Elementul central în definirea sepsisului este reprezentat de disfunctia de organ, reprezentând o modificare acută a scorului SOFA $\geq 2$ puncte consecutivă unei infectii. Utilizarea criteriilor SIRS în identificarea pacienților cu sepsis a fost abandonată, iar subcategoria „sepsis sever” a fost eliminată. Absența biomarkerilor specifici pentru sepsis rămâne o mare problemă şi din acest punct de vedere studiile nu au găsit încă un răspuns. Mai multe miRNAs au fost găsite diferit exprimate la pacienții cu sepsis, dar majoritatea studiilor publicate până acum au eşuat în a găsi potențialii biomarkeri care ar putea diferenția sepsisul de SIRS. O soluție a acestei probleme pare a fi analiza rețelelor de miRNA în sepsis. 
Cuvinte cheie: definiții sepsis, biomarkeri specifici, microARN, rețele microARN

\section{Abstract}

Sepsis represents a systemic illness, characterized by life-threatening organ dysfunction induced by infection. Early diagnostic, evaluation of severity of sepsis with aggressive resuscitation and administration of appropriate antibiotics are associated with improved outcomes. In 2016 a new definition of sepsis (Sepsis-3) was proposed. The key element of sepsis-induced organ dysfunction is defined by 'an acute change in total SOFA score $\geq 2$ points consequent to infection'. The use of SIRS criteria as identification of sepsis was abandoned and subcategory of severe sepsis was eliminated. A wide spectrum of biomarkers had been proposed for potential use in sepsis, more than in other diseases, outlying the complex pathophysiology of this condition. The first study reporting the clinical value of circulating miRNAs in sepsis showed that both leukocytes and plasma miR-150 levels are significantly reduced in sepsis patients compared with controls and correlate with sepsis severity. Several miRNAs were found differentially expressed in sepsis patients, but most of the published studies failed to find miRNA biomarkers that could differentiate sepsis from SIRS. A solution to this problem seems to be building and analyzing miRNA network in sepsis patients.

Key words: sepsis definitions, specific biomarkers, miRNAs, miRNA network

\section{Introduction}

With all of the progresses in the field of diagnostic and treatment, sepsis remains the leading cause of death in Intense Care Unit (ICU) in USA with a mortality rate of $28.6 \%$ (range 20\% to 50\%) (1). Across Europe more than $35 \%$ of ICU patients had sepsis at some point during their ICU stay with an overall hospital mortality rate of $24,1 \%$ (range $14 \%$ to 41\%) (2). Although the mortality rate among patients with sepsis is declining the number of patients dying from sepsis is growing as more patients are affected $(3,4)$.

Early diagnostic and evaluation of severity of sepsis with aggressive resuscitation and administration of appropriate antibiotics are associated with improved outcomes (5).

\section{Sepsis Definitions}

In 1914, Schottmueller H.6, a student of German physician H. Lennhartz, proposed the first definition of sepsis: "Sepsis is present if a focus has developed from which pathogenic bacteria, constantly or periodically, invade the blood stream in such a way that this causes subjective and objective symptoms" (6).

In 1992, a North American consensus conference was defining criteria for sepsis and introduced the idea that sepsis is the host's inflammatory response to infection. The first definition of the septic syndrome (Sepsis-1) was based on the concomitant presence of presumed or confirmed infection and at least two Systemic Inflammatory Response Syndrome (SIRS) criteria 7 (Table 1). In the same conference severe sepsis was defined as sepsis with organ dysfunction, hypoperfusion or hypotension and septic shock as "persisting sepsis-induced hypotension despite adequate fluid resuscitation" (7).

In 2001, SCCM/ESICM/ACCP/ATS/SIS International Sepsis Definitions Conference 8 introduced an updated list of signs and symptoms of sepsis (Sepsis-2), but didn't change definition for sepsis. The primary point of the conference was: "The current concepts of sepsis, severe sepsis, and septic shock seem to be robust definitions and should remain as described 10 years ago"(8). 
Table 1. Systemic Inflammatory Response Syndrome (SIRS) criteria (7)

\begin{tabular}{ll}
\hline Temperature & $>38^{\circ} \mathrm{C}$ or $<36^{\circ} \mathrm{C}$ \\
\hdashline Heart rate & $>90 / \mathrm{min}$ \\
\hline Respiratory rate & $>20 / \mathrm{min}$ or $\mathrm{PaCO} 2<32 \mathrm{mmHg}$ \\
White blood cell count & $>12000 / \mathrm{mm}^{3}$ or $<4000 / \mathrm{mm}^{3}$ or \\
& $>10 \%$ immature bands \\
\hline
\end{tabular}

In 2016 a new definition of sepsis (Sepsis-3) was proposed by SCCM/ESICM (9). Sepsis is now considered a life-threatening organ dysfunction due a dysregulated systemic inflammatory and immune response to microbial invasion that can produce organ injury. The key element of sepsis-induced organ dysfunction is defined by 'an acute change in total SOFA score $\geq 2$ points consequent to infection', reflecting an overall mortality rate of approximately 10\%" (9). The use of SIRS criteria as identification of sepsis was abandoned and subcategory of severe sepsis was eliminated. Septic shock was defined as a 'subset of sepsis where underlying circulatory and cellular/ metabolic abnormalities are profound enough to substantially increase mortality'. Criteria identifying these condition include: the need for vasopressors to obtain a $\mathrm{MAP} \geq 65 \mathrm{mmHg}$ and an increase in lactate concentration $>2 \mathrm{mmol} / \mathrm{L}$. This new definition is mainly focused on the importance to distinguish septic shock from other forms of circulatory shock and underline the detrimental clinical impact of sepsisinduced cellular metabolism abnormalities (9). Sepsis patients, identified according to the new (Sepsis-3) criteria have higher mortality compared with those identified according with Sepsis-2 criteria. The new definitions select a smaller, but more critically ill, subcategory of patients (10).

The SOFA scoring system is commonly used in intensive care units, but due to its complexity it may delay the time of sepsis identification and diagnosis. A simplified tool to identify patients potentially at risk of dying from sepsis was introduced: quick SOFA (qSOFA) consisting in only three criteria (Table 2).

The presence of at least two of these criteria indicates organ dysfunction. The
Table 2. qSOFA scoring system

\begin{tabular}{lc}
\hline Criteria & Points \\
\hline Changed in mental status & 1 \\
\hdashline Respiratory rate $\geq 22 / \mathrm{min}$ & 1 \\
\hline Systolic blood pressure $\leq 100 \mathrm{mmHg}$ & 1 \\
\hline
\end{tabular}

qSOFA score does not require laboratory tests and can be used quickly at the bedside.

The use of qSOFA in detection of patients with sepsis was studied and some authors raised the concern that qSOFA has a poor sensitivity and cannot be used as screening tool for early sepsis, when the treatment is the most effective (11).

\section{miRNA Biomarkers}

Due to a fact that gold standard for diagnostic and treatment of sepsis is still a matter of debate, a wide spectrum of biomarkers, more than in other diseases, had been proposed for potential use in sepsis, outlying the complex pathophysiology of this condition. More of 180 different sepsis biomarkers have been reported in the literature until 2010 (12), none of them with sufficient specificity or sensitivity to be introduced in clinical practice. At present, the promising biomarkers of sepsis are procalcitonin, interleukin- 6 and C-reactive protein, but neither fulfills the role of an ideal biomarker of sepsis. The search for biomarkers with excellent clinical testing performance goes on (12-16).

MicroRNAs (miRNAs) are small noncoding RNAs (ncRNAs), consisting of 19-24 nucleotides with gene regulatory functions. Changes in miRNA expression play an important role in the regulation of the immune response.

Since the discovery of microRNAs (miRNAs) in $1993(17,18)$ more than 2815 miRNAs have been described in humans (19). A significant number of miRNAs are found at intracellular level. Several studies report the existence of a significant number of miRNAs outside the cell, called circulating miRNAs (20). Extracellular miRNAs have been identified in several biological 
fluids, such as blood, urine, saliva, peritoneal fluid, amniotic fluid, bronchial lavage, cerebrospinal fluid, and tears (21).

Published in 2009, the first study reporting the clinical value of circulating miRNAs in sepsis, showed that miR-150 levels in both leukocytes and plasma were significantly reduced in sepsis patients compared with controls and correlated with the level of sepsis severity (22). Several following studies found lower miR-150 levels in sepsis patients and the correlation with severity of sepsis, suggesting the use of miR-150 as prognostic factor $(23,24)$.

miR-223 and miR-146a represent two of the most researched miRNAs involved in the pathogenesis of various diseases. Wang et al. demonstrated that miR-223 and miR-146a are dysregulated in sepsis patients (25). Serum levels of miR-146a and miR-223 were significantly reduced in sepsis patients compared to SIRS patients and healthy individuals. Importantly, there were no significant changes in miR-223 levels in SIRS patients compared to healthy individuals (26). miR-223 can be a useful tool to differentiate infectious from non-infectious SIRS. Recently, one study profiled serum miRNAs of 214 sepsis patients (117 survivors and 97 non- $^{-}$ survivors) found that miR-223 levels were significantly lower in non-survivors compared to survivors (26).

Until now there are no published papers studying the miRNAs in sepsis patients identified according to new definition. Taking into account that the old definition of sepsis was focusing on inflammation rather than organdysfunction, the interpretation of miRNAs as a biomarkers may be altered. Focused on organ dysfunction, the new sepsis-definition may change the role of miRNAs in diagnosis and treatment of sepsis patients.

Most published research tried and failed to demonstrate the potential role of miRNA as biomarkers that could differentiate sepsis from SIRS because focusing solely on profiling the miRNA signature in plasma/blood cells. A solution to this problem was proposed in 2017 by Vasilescu et al. (20) using the network theory, as a method to describe complex biological systems, building the miRNA network in septic patients and compare it to miRNA network in healthy controls. According to the authors the miRNA network in sepsis is less connected, the miRNAs seem to be "sponged", sequester; hence, the activity of these miRNAs is altered. Understanding the dynamics of miRNA network in sepsis offer the possibility to discover diagnostic and therapeutic strategies targeting components of the immune response.

\section{Conclusion}

Early diagnosis, evaluation of severity of sepsis and aggressive treatment are associated with improved outcomes. Sepsis is considered now a life-threatening organ dysfunction due a dysregulated systemic inflammatory and immune response to microbial invasion that can produce organ injury. Septic shock is considered a subset of sepsis where underlying circulatory and cellular/metabolic abnormalities are profound enough to substantially increase mortality. This new definition is mainly focused on the importance to distinguish septic shock from other forms of circulatory shock and underline the detrimental clinical impact of sepsis-induced cellular metabolism abnormalities. The absence of sepsis specific biomarkers remains an important problem and from this point of view sepsis studies are limited. Several miRNAs were found differentially expressed in sepsis patients, but most of the published studies failed to find miRNA biomarkers that could differentiate sepsis from SIRS. A solution to this problem seems to be building and analyzing miRNA network in sepsis patients.

\section{Conflicts of Interest}

No conflict of interest.

\section{Authors' Contributions}

Study conception and design: Gratiela Manga, Gabriela Droc, Stefan Tudor.

Drafting of manuscript: Gratiela Manga, George A. Calin, Mircea Manuc, Stefan Tudor

Critical revision of manuscript: Gratiela Manga, Gabriela Droc, Stefan Tudor 


\section{References}

1. Angus DC, Linde-Zwirble WT, Lidicker J, Clermont G, Carcillo J, Pinsky MR. Epidemiology of severe sepsis in the United States: analysis of incidence, outcome, and associated costs of care. Crit Care Med. 2001;29(7):1303-10.

2. Vincent JL, Sakr Y, Sprung CL, Ranieri VM, Reinhart K, Gerlach H, et al. Sepsis in European intensive care units: results of the SOAP study. Crit Care Med. 2006;34(2):344-53.

3. Vincent JL, Abraham E. The last 100 years of sepsis. Am J Respir Crit Care Med. 2006;173(3):256-63.

4. Martin GS, Mannino DM, Eaton S, Moss M. The epidemiology of sepsis in the United States from 1979 through 2000. N Engl J Med. 2003;348(16):1546-54.

5. Ferrer R, Artigas A, Suarez D, Palencia E, Levy MM, Arenzana A, et al. Effectiveness of treatments for severe sepsis: a prospective, multicenter, observational study. Am J Respir Crit Care Med. 2009; 180(9):861-6. PubMed PMID: 19696442.

6. Schottmueller H. Wesen und Behandlung der Sepsis. Inn Med. 1914;31:257-80.

7. Bone RC, Sprung CL, Sibbald WJ. Definitions for sepsis and organ failure. Crit Care Med. 1992;20(6):724-6.

8. Levy MM, Fink MP, Marshall JC, Abraham E, Angus D, Cook D, et al 2001 SCCM/ESICM/ACCP/ATS/SIS International Sepsis Definitions Conference. Crit Care Med. 2003;31(4):1250-6.

9. Singer M, Deutschman CS, Seymour CW, Shankar-Hari M, Annane D, Bauer M, et al. The Third International Consensus Definitions for Sepsis and Septic Shock (Sepsis-3). JAMA. 2016;315(8):801-10.

10. Driessen RGH, van de Poll MCG, Mol MF, van Mook W, Schnabel RM. The influence of a change in septic shock definitions on intensive care epidemiology and outcome: comparison of sepsis-2 and sepsis-3 definitions. Infect Dis (Lond). 2018;50(3):207-13.

11. Williams JM, Greenslade JH, McKenzie JV, Chu K, Brown AFT, Lipman J. Systemic Inflammatory Response Syndrome, Quick Sequential Organ Function Assessment, and Organ Dysfunction: Insights From a Prospective Database of ED Patients With Infection. Chest. 2017;151(3):586-96.

12. Pierrakos C, Vincent JL. Sepsis biomarkers: a review. Crit Care. 2010;14(1):R15.

13. Vasilescu C, Olteanu M, Flondor P. How relevant are in vivo and in vitro studies for clinical sepsis? A mathematical model of LPS signaling based on endotoxin tolerance. Chirurgia (Bucur). 2009; 104(2):195-201.
14. Berger D, Boelke E, Stanescu A, Buttenschoen K, Vasilescu C, Seidelmann $\mathrm{M}$, et al. Endotoxemia and mediator release during colonoscopy. Endoscopy. 1995;27(9):671-5.

15. Vasilescu C, Berger D, Buttenschon K, Seidelmann M, Beger HG. Endotoxin-induced release of interleukin 6 and interleukin 1 beta in human blood is independent of tumor necrosis factor alpha. Eur Surg Res. 1996;28(1):55-62.

16. Buttenschoen K, Buttenschoen DC, Berger D, Vasilescu C, Schafheutle S, Goeltenboth B, et al. Endotoxemia and acute-phase proteins in major abdominal surgery. Am J Surg. 2001;181(1):36-43.

17. Lee RC, Feinbaum RL, Ambros V. The C. elegans heterochronic gene lin-4 encodes small RNAs with antisense complementarity to lin-14. Cell. 1993;75(5):843-54.

18. Wightman B, Ha I, Ruvkun G. Posttranscriptional regulation of the heterochronic gene lin-14 by lin-4 mediates temporal pattern formation in C. elegans. Cell. 1993;75(5):855-62.

19. miRBase: The microRNA Database.; Available from: http:// www.mirbase.org

20. Vasilescu C, Dragomir M, Tanase M, Giza D, Purnichescu-Purtan R, Chen $\mathrm{M}$, et al. Circulating miRNAs in sepsis-A network under attack: An in-silico prediction of the potential existence of miRNA sponges in sepsis. PLoS One. 2017;12(8):e0183334.

21. Cortez MA, Bueso-Ramos C, Ferdin J, Lopez-Berestein G, Sood AK, Calin GA. MicroRNAs in body fluids--the mix of hormones and biomarkers. Nat Rev Clin Oncol. 2011;8(8):467-77.

22. Vasilescu C, Rossi S, Shimizu M, Tudor S, Veronese A, Ferracin M, et al. MicroRNA fingerprints identify miR-150 as a plasma prognostic marker in patients with sepsis. PLoS One. 2009 Oct 12;4(10):e7405.

23. Ma Y, Vilanova D, Atalar K, Delfour O, Edgeworth J, Ostermann M, et al. Genome-wide sequencing of cellular microRNAs identifies a combinatorial expression signature diagnostic of sepsis. PLoS One. 2013;8(10):e75918.

24. Roderburg C, Luedde M, Vargas Cardenas D, Vucur M, Scholten D, Frey N, et al. Circulating microRNA-150 serum levels predict survival in patients with critical illness and sepsis. PLoS One. 2013;8(1):e54612.

25. Wang JF, Yu ML, Yu G, Bian JJ, Deng XM, Wan XJ, et al. Serum miR-146a and miR-223 as potential new biomarkers for sepsis. Biochem Biophys Res Commun. 2010;394(1):184-8.

26. Wang L, Wang HC, Chen C, Zeng J, Wang Q, Zheng L, et al. Differential expression of plasma miR-146a in sepsis patients compared with non-sepsis-SIRS patients. Exp Ther Med. 2013; 5(4):1101-4. 